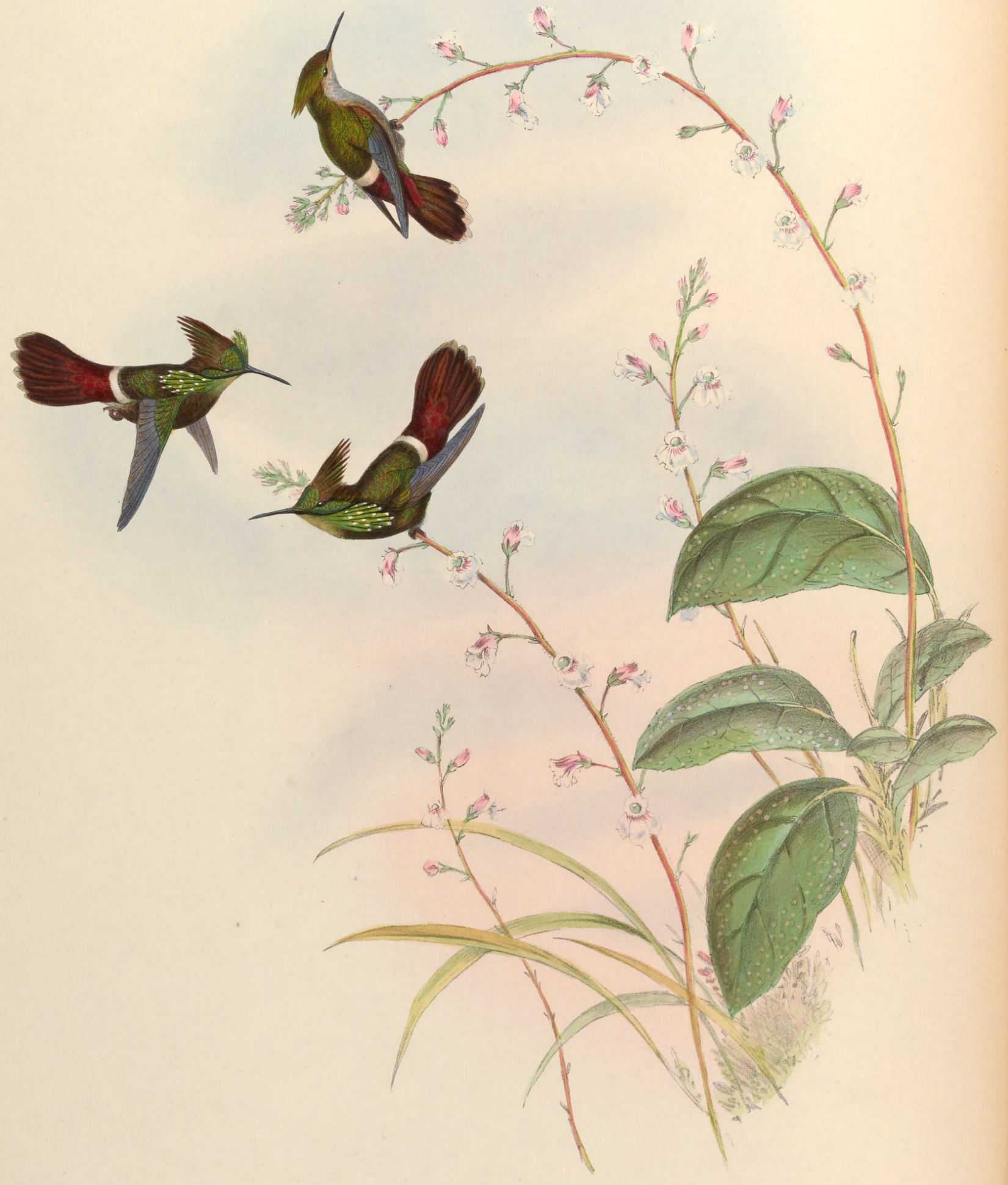




\title{
LOPHORNIS VERREAUXI.
}

\section{Peruvian Coquette.}

\author{
Trochilus Verreauxi, Bourc. Rev. Zool. 1853, p. 193. \\ Lophornis Verreauxi, Reichenb. Auf. der Col., p. 12. \\ Bellatrix verreauxi, Bonap. Rev. et Mag. de Zool. 1854, p. 257.
}

THis species may be justly regarded as one of the most precious of the Humming-Birds, and it consequently ranks most highly in my estimation. It is a native of Peru, and the only specimens I have ever seen are in the collection of my friend M. Edouard Verreaux of Paris, after whom the bird has been named, as a just compliment to that gentleman's zeal for the promotion of natural science, particularly Ornithology. M. Verreaux has, with the utmost kindness and confidence, allowed me the use of these rarities in London for the purpose of enriching the present work; and I trust that both myself and my readers are duly sensible of his liberality in so doing.

The discovery of this bird will, I am sure, sufficiently bear out what I have so often said in other parts of this work respecting the little we yet know of the natural productions of those great ranges of mountains, the Cordilleras and the Andes, where, between the line of perpetual congelation and the hot valleys at their bases, so much diversity of country and climate occurs, that an area of a hundred leagues is almost equal to a continent in other parts of the globe. It is in some one of these hot valleys that in all probability this bird finds a congenial habitat, the confines of which it may possibly never leave : I am led to surmise this from the circumstance of some of the extinct volcanos having a fauna and a flora almost peculiar to themselves, and from the evidence afforded by the fact that the great snow-covered peaks of Chimborazo, Pichincha, Cotopaxi, \&c., have their sides, immediately below their snow-lines, tenanted by species not to be found elsewhere. How long a time must elapse before we can become acquainted with all the productions of the great back-bone, so to call it, of the vast continent of America, stretching along its western side from Cape Horn to the Rocky Mountains!

The bird most nearly allied to this species is the Lophornis chalybeus of Brazil ; but that bird, beautiful as it is, must give place to the $L$.Verreauxi, which, besides being more richly coloured, is adorned with a fine crest, - a character which appears to be common to both sexes, unless the specimen from which $I$ have figured should prove to be a young male. I possess a skin from Bogota without a crest, which I have for a long time regarded as a female $L$.Verreauxi ; if this should not be the case, there is yet another fine species, the male of which is unknown to us.

Forehead and patch below the eye glittering metallic grass-green; crest, back of the neck, wing-coverts, and abdomen deep oil-green, darkest on the latter; wings purplish brown; at the lower part of the back a narrow band of white ; upper tail-coverts and tail deep chestnut-red, becoming darker towards the end, and slightly tipped with a greyish buff; throat and tuft on each side of the neck pale green, each feather of the latter with an oval spot of white at the tip.

The female has the head and crest brown; the general plumage paler than in the male; the band across the lower part of the back buffy white; the throat grey, and the tail more largely tipped with buffy white.

The Plate represents the male in two positions and the female, all of the natural size. The plant is the

Achimenes argyrostigma. 


\section{$2 \mathrm{BHL}$ Biodiversity Heritage Library}

Gould, John. 1855. "Lophornis verreauxi, Peruvian Coquette. [PI. 125]." A monograph of the Trochilidae, or family of humming-birds 3, https://doi.org/10.5962/p.316934.

View This Item Online: https://www.biodiversitylibrary.org/item/109468

DOI: https://doi.org/10.5962/p.316934

Permalink: https://www.biodiversitylibrary.org/partpdf/316934

\section{Holding Institution}

Smithsonian Libraries

\section{Sponsored by}

Smithsonian Institution Libraries

\section{Copyright \& Reuse}

Copyright Status: NOT_IN_COPYRIGHT

This document was created from content at the Biodiversity Heritage Library, the world's largest open access digital library for biodiversity literature and archives. Visit BHL at https://www.biodiversitylibrary.org. 